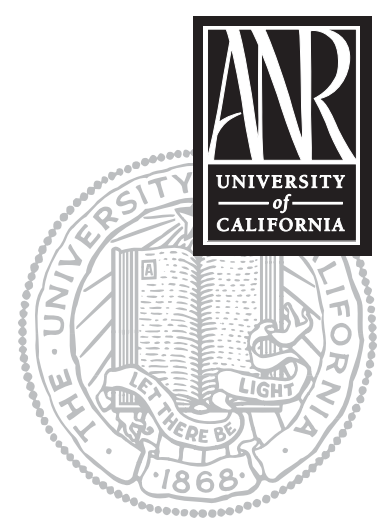

UNIVERSITY OF CALIFORNIA

Division of Agriculture and Natural Resources http://anrcatalog.ucdavis.edu

\title{
Understanding Soil Erosion in Irrigated Agriculture
}

ANTHONY TOBY O'GEEN, UC Cooperative Extension Assistant Soil Resource Specialist, Department of Land, Air, and Water Resources, UC Davis; and LAWRENCE J. SCHWANKL, UCCE Irrigation Specialist, Department of Land, Air, and Water Resources, Kearney Agricultural Center.

\section{IMPACTS OF SOIL EROSION}

Soil erosion is caused by the erosive forces of wind or water. In this publication, we focus our attention on concepts surrounding water-induced soil erosion. This type of erosion threatens our ability as humans to sustain our global population with food and fiber, and is closely linked to economic vitality, environmental quality, and human health concerns. Roughly 75 billion tons of fertile topsoil is lost worldwide from agricultural systems every year. In the United States, we lose an estimated 6.9 billion tons of soil each year (Pimentel, 2000). Losses at this scale are not sustainable and result in our increasing dependence on costly inputs such as fertilizers and soil amendments that we use in an attempt to make up for the beneficial qualities that were present in the lost topsoil (Pimentel, 2000).

Erosion results in the degradation of a soil's productivity in a number of ways: it reduces the efficiency of plant nutrient use, damages seedlings, decreases plants' rooting depth, reduces the soil's water-holding capacity, decreases its permeability, increases runoff, and reduces its infiltration rate. The loss of nutrients alone resulting from soil erosion has an estimated cost to the United States of up to $\$ 20$ billion a year (Troeh, Hobbs, and Donahue, 1991). The sediment deposited by erosive water as it slows can bury seedlings and cause the formation of surface crusts that impede seedling emergence, which will decrease the year's crop yields. The combined effects of soil degradation and poor plant growth often result in even greater erosion later on.

All of these effects occur at or near the erosion site. Off-site impacts relate to the transport of sediment, nutrients, and agricultural chemicals and can be even more costly than on-site impacts. Severe economic and environmental costs are associated with the removal of sediment deposits from roads and from lakes and other surface water bodies. In the United States, more than 60 percent of water-eroded soils (about 2.4 billion tons of soil a year) end up in watercourses (Pimentel, 2000). This leads to the sedimentation of dams, disruption of aquatic ecosystems, and contamination of drinking water supplies.

The information in this publication is intended to help you maintain the productivity of agricultural land and reduce the enormous costs associated with erosion by promoting a better understanding of the soil erosion process, providing tools to help you recognize soil erosion, and introducing management practices that you can use to help reduce this kind of erosion.

\section{TYPES OF WATER EROSION}

In general, soil erosion is a three-step process. It begins with the detachment of soil particles, continues with the transport of those particles, and ends with the deposition of soil particles in a new location. Bare soils (soils that lack a cover of living or dead plant biomass) are highly susceptible to erosion, even on flat land. There are three main types of water- induced soil erosion: sheet, rill, and gully. 

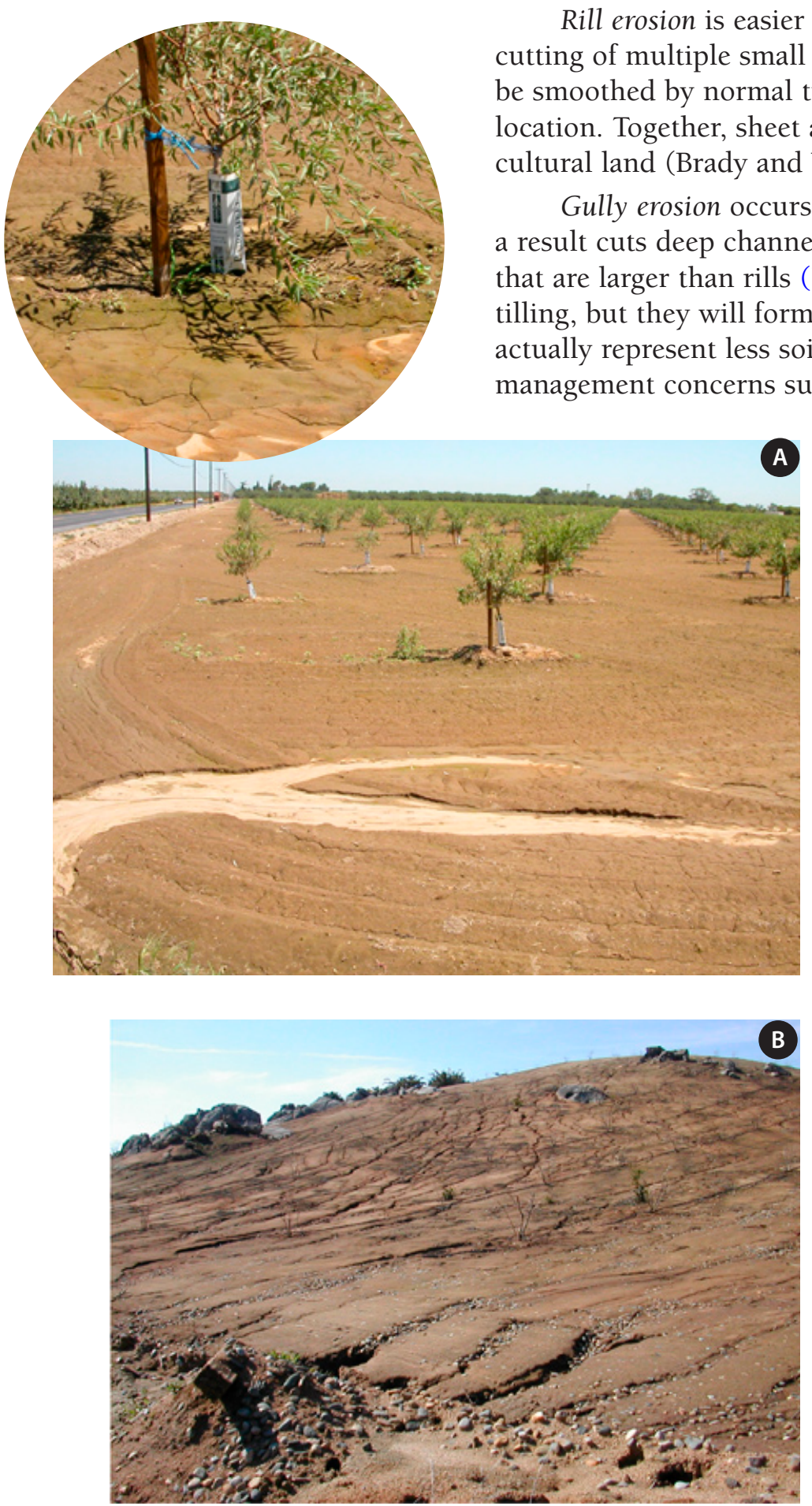

Figure 1. Examples of sheet and rill erosion. (A) Sheet and rill erosion in California's Central Valley (Photo by Toby O'Geen). (B) Note the exposed rock fragments from sheet erosion and the network of rills running across the hill slope (Photo courtesy of Kerry Arroues, USDA-NRCS).
The most common yet most overlooked form of soil loss is sheet erosion. Sheet erosion is the uniform removal of a thin film of soil from the land surface without the development of any recognizable water channels (Figure 1). This type of erosion is barely perceptible, but the loss of a single millimeter of soil depth from an acre of land, which can be easily lost during a single irrigation or rain event, works out to a total loss of up to 6.1 tons of soil (Pimentel, 2000).

Rill erosion is easier to recognize. It is the removal of soil through the cutting of multiple small water channels (Figure 1). Rills are small enough to be smoothed by normal tillage operations and will not form again in the same and rill erosion account for most soil erosion in agri-

Gully erosion occurs in areas where water runoff is concentrated, and as a result cuts deep channels into the land surface. Gullies are incised channels that are larger than rills (Figure 2). You can remove small, ephemeral gullies by again in the same location on the landscape. Gullies , represent less soil loss than sheet or rill erosion, but they pose added equipment, and increased labor costs to repair eroded areas.

\section{INDICATORS OF SOIL EROSION}

It is important for you to be able to recognize evidence of soil erosion in the field. Here are some visual indicators that you can watch for (USDANRCS, 2001):

- bare soil

- plants or rocks on pedestals

- exposed roots

- small benches of soil behind obstacles

- surface soil crusts

- increased tendency of runoff water to flow together into a network of connected channels

- deposits of soil where the field's slope changes

- decreased thickness of topsoil

- exposed subsoil at the soil surface

- visible rills or gullies

- silt-clouded water or sediment deposits in surface water bodies and irrigation canals

- poor plant growth

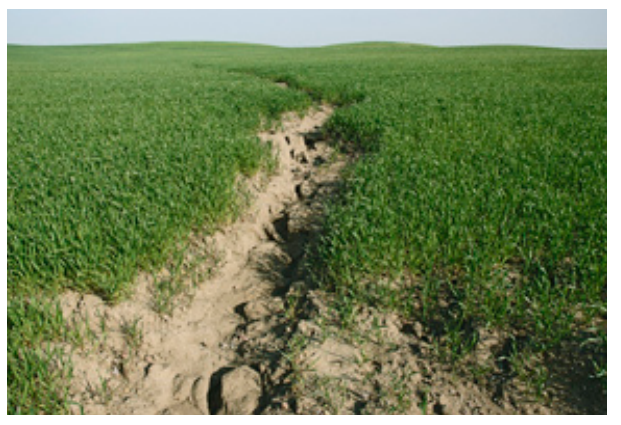

Figure 2.

Example of gully erosion. Photo courtesy of Vic Claassen, UD Davis. 
Table 1. Definitions of LCCS classes

\begin{tabular}{l|l}
\hline $\begin{array}{l}\text { LCCS } \\
\text { class }\end{array}$ & LCCS class definition \\
\hline I & Few limitations \\
\hline II & $\begin{array}{l}\text { Moderate limitations that require } \\
\text { limited conservation practices }\end{array}$ \\
\hline III & $\begin{array}{l}\text { Severe limitations that require special } \\
\text { conservation practices }\end{array}$ \\
\hline IV & $\begin{array}{l}\text { Very severe limitations that require } \\
\text { careful management }\end{array}$ \\
\hline V & $\begin{array}{l}\text { Soils are not likely to erode, but have } \\
\text { other limitations, impractical to remove }\end{array}$ \\
\hline VI & $\begin{array}{l}\text { Severe limitations that make soils } \\
\text { generally unsuitable for cultivation }\end{array}$ \\
\hline VII & $\begin{array}{l}\text { Very severe limitations that make soils } \\
\text { unsuitable for cultivation }\end{array}$ \\
\hline VIII & $\begin{array}{l}\text { Soils with limitations that nearly } \\
\text { preclude their use for commercial crop } \\
\text { production }\end{array}$ \\
\hline
\end{tabular}

Table 2. Definitions of LCCS units

\begin{tabular}{l|l}
\hline $\begin{array}{l}\text { LCCS } \\
\text { units }\end{array}$ & Cause of limitation \\
\hline 1 & $\begin{array}{l}\text { Limitation caused by slope or by actual } \\
\text { or potential erosion hazard }\end{array}$ \\
\hline 2 & $\begin{array}{l}\text { Limitation of wetness caused by poor } \\
\text { drainage or flooding }\end{array}$ \\
\hline 3 & $\begin{array}{l}\text { Slow or very slow permeability of the } \\
\text { subsoil }\end{array}$ \\
\hline 4 & $\begin{array}{l}\text { Sandy or gravelly soils with very low or } \\
\text { low available water-holding capacity }\end{array}$ \\
\hline 5 & $\begin{array}{l}\text { Fine-textured or very fine-textured } \\
\text { surface layer }\end{array}$ \\
\hline 6 & Sodicity or salinity \\
\hline 7 & High rock, stone, or cobble content \\
\hline 8 & $\begin{array}{l}\text { Shallow depth to bedrock (less than } 40 \\
\text { inches [about } 1 \text { meter]) }\end{array}$ \\
\hline 9 & Poor fertility that cannot be corrected \\
\hline 10 & $\begin{array}{l}\text { High rock, stone, cobble, or gravel } \\
\text { content in subsoil }\end{array}$ \\
\hline
\end{tabular}

Sources: Soil Survey Division Staff, 1993.

\section{SOIL SURVEY INTERPRETATIONS}

An additional tool to understanding the erosion potential of your land is a USDA-NRCS Soil Survey Report. You can get a hard copy of the relevant soil survey at a local NRCS office. New and future soil surveys will only be published online as PDF (Adobe Acrobat) documents at this URL: http://www.ca.nrcs.usda.gov/mlra02/.

You can find information about erosion at the field scale in a number of sections of a soil survey report. After you have used the soil survey report to identify the soil map unit(s) of interest, use the report's table of contents and summary of tables to guide you to the relevant pages. The erosion hazard rating describes the potential for erosion damage in terms of severity, ranging from slight to severe. This rating appears in the Detailed Soil Map Units section of your soil survey. Similar information for forested lands can be found in the Woodland Management and Productivity table.

Erosion is also listed as a land use limitation in the Water Management table. Soil erodibility and soil loss tolerance estimates for each map unit are found in the Physical and Chemical Properties of the Soils table. The Land Capability Classification System is used to evaluate soils for land use in soil surveys. It also contains information about the erodibility of a landscape.

\section{LAND CAPABILITY CLASSIFICATION SYSTEM}

The land capability classification system (LCCS) can be used to understand the production potential and erodibility of your land. In the LCCS, soils are generally grouped at three levels: capability class, subclass, and units. Not all soil survey reports list all three classification levels, however. Some reports only use the capability class and subclass levels. The soil's LCCS rating appears in the text of the Detailed Soil Map Units section. Some soil surveys also display it as a separate table. See your soil survey report's summary of tables or table of contents for clarification on this point.

Capability classes are the broadest groupings of land and are designated by Roman numerals I through VIII. Limitations on land use increase with higher numbers. The classes are explained in Table 1.

Capability subclass $e$ (for example, subclass $2 e$ ) is added to the capability class number when there is risk associated with soil erosion. Classes I and V rarely have the letter $e$ because they are subject to little or no erosion. Capability units are soil groups within a subclass. The capability unit code provides information on the cause of the limitation. Capability units are generally designated by adding an Arabic numeral to the subclass code. For example, IIe- 3 and IIIe- 6 indicates that the erodibility of these sites is caused by slow permeability and saltaffected soil, respectively (Table 2 ).

\section{SOIL EROSION FACTORS (K AND T)}

Soil erosion factors (K and T), are found in soil survey reports in the Physical and Chemical Properties of Soils table. The soil loss tolerance factor $(T)$ is an estimate of the maximum average annual rate of soil loss (in tons per acre) that can occur without significantly affecting crop productivity. $\mathrm{T}$ values are established based on the following factors: 
- maintaining adequate soil depth

- value of nutrients lost

- maintaining water-control structures and control of floodplain sedimentation

- prevention of gullies

- yield reduction per inch of topsoil lost

- water losses

- seedling losses

$\mathrm{T}$ factors are important in the evaluation and development of conservation practices that reduce soil erosion (Schertz and Nearing, 2002).

The soil erodibility factor $(K)$ describes erodibility based solely on the physical properties of the soil. You can find a detailed discussion of the $\mathrm{K}$ factor in the companion publication Erodibility of Agricultural Soils, with Examples in Lake and Mendocino Counties (UC ANR Publication 8194).

\section{NEW SOIL SURVEY RESOURCES}

The UC Davis Soil Resource Laboratory has developed an online soil survey browser that allows users to navigate across the state of California using point-and-click operations to access soil survey data. You can find this user-friendly soil survey tool at this URL: http://casoilresource.lawr.ucdavis.edu/.

The USDA-NRCS has also developed a nationwide Web soil survey interface that will allow users to create maps of specific soil properties for any region that has a published soil survey. This product is available at this URL: http://websoilsurvey.nrcs. usda.gov/app/.

\section{SUMMARY}

In all instances, we must consider soil to be a non-renewable resource. The rate of soil formation is very slow: it takes from 300 to 1000 years for nature to replace the soil that a field can lose to erosion in 25 years at a loss rate of $1 \mathrm{~mm}$ per year (Pimentel et al., 1976). In order to manage soils in a sustainable manner, we must take steps to reduce soil erosion.

\section{REFERENCES}

Brady, N. C., and R. R. Weil. 1999. Soil erosion and its control. In The nature and properties of soils. 12th edition, page 680. Upper Saddle River, NJ: Prentice Hall Inc.

Pimentel, D., E. C. Terhune, R. Dyson-Hudson, S. Rochereau, R. Samis, E. A. Smith, D. Denman, D. Reifschneider, and M. Shepard. 1976. Land degradation: Effects on food and energy resources. Science 94:149-155.

Pimentel, D. 2000. Soil erosion and the threat to food security and the environment. Ecosystem Health 6:221-226.

Schertz, D. L., and M. A. Nearing. 2002. Erosion tolerance/soil loss tolerances. In Encyclopedia of soil science, R. Lal (ed.). New York: Marcel Dekker, Inc.

Soil Survey Division Staff. 1993. Soil survey manual. Washington, DC: U.S. Government Printing Office. Soil Conservation Service. U.S. Department of Agriculture Handbook 18.

Troeh, R. R., J. A. Hobbs, and R. L. Donahue. 1991. Soil and water conservation. Englewood Cliffs, NJ: Prentice Hall. 
USDA-NRCS. 2001. Rangeland soil quality: Water erosion. Soil Quality

Information Sheet, available online: http://soils.usda.gov/sqi

\section{FOR MORE INFORMATION}

You'll find related information in these titles and in other publications, slide sets, CDROMs, and videos from UC ANR:

Erodibility of Agricultural Soils, with Examples in Lake and Mendocino Counties, Publication 8194

Sediment Delivery Inventory and Monitoring: A Method for Water Quality Management in Rangeland Watersheds, Publication 8014

Vegetative Filter Strips for Nonpoint Source Pollution Control in Agriculture, Publication 8195

To order these products, visit our online catalog at http://anrcatalog.ucdavis.edu. You can also place orders by mail, phone, or FAX, or request a printed catalog of publications, slide sets, CD-ROMs, and videos from

University of California

Agriculture and Natural Resources

Communication Services

6701 San Pablo Avenue, 2nd Floor

Oakland, California 94608-1239

Telephone: (800) 994-8849 or (510) 642-2431

FAX: (510) 643-5470

E-mail inquiries: danrcs@ucdavis.edu

An electronic version of this publication is available on the ANR Communication Services Web site at http://anrcatalog.ucdavis.edu.

Publication 8196

ISBN-13: 978-1-60107-389-1

ISBN-10: 1-60107-389-5

This publication has been anonymously peer reviewed for technical accuracy by University of California scientists and other qualified professionals. This review process was managed by the ANR Associate Editor for Land, Air, and Water Sciences.

(C)2006 by the Regents of the University of California

Division of Agriculture and Natural Resources.

All rights reserved.

The University of California prohibits discrimination or harassment of any person on the basis of race, color, national origin, religion, sex, gender identity, pregnancy (including childbirth, and medical conditions related to pregnancy or childbirth), physical or mental disability, medical condition (cancer-related or genetic characteristics), ancestry, marital status, age, sexual orientation, citizenship, or status as a covered veteran (covered veterans are special disabled veterans, recently separated veterans, Vietnam era veterans, or any other veterans who served on active duty during a war or in a campaign or expedition for which a campaign badge has been authorized) in any of its programs or activities.

University policy is intended to be consistent with the provisions of applicable State and Federal laws.

Inquiries regarding the University's nondiscrimination policies may be directed to the Affirmative Action/Staff Personnel Services Director, University of California, Agriculture and Natural Resources, 300 Lakeside Drive, 6th Floor, Oakland, CA 94612-3550, (510) 987-0096. For information about obtaining this publication, call (800) 994-8849. For downloading information, call (530) 297-4445.

pr-08/06-WJC/CAM 